slightly earlier than the dates for the north-west. But in 1941 the north-west dates of this flower were slightly earlier than the south-east dates. Despite the War, reports were sent in from 277 phenological observers in the scheme-only twelve less than the previous year.

\section{Tuberculosis in Ecuador}

IN a recent article (Bol. Of. San. Panamericana, 21,$128 ; 1942$ ), Dr. Jorge Higgins, director of the Anti-tuberculous Dispensary of Guayaquil, Ecuador, states that of Ecuador's three geographical regions, the coast, which has an average temperature of $81^{\circ} \mathrm{F}$., is the most severely affected by tuberculosis. The port of Guayaquil, which has a population of 200,000 , has the highest tuberculosis mortality in the world. The anti-tuberculosis campaign began in 1934, when the first dispensary in Guayaquil was established. A similar dispensary was afterwards opened in Quito, and more are being planned for the rest of Ecuador. During 1939, the Guayaquil dispensary provided 2,609 medical consultations, 2,406 fluoroscopic examinations, 683 pleural insufflations and 1,431 laboratory examinations; 1,169 patients were admitted and 1,831 home visits were made. A large sanatorium has been started in Guayaquil sup. ported by a new organization called the Liga Antituberculosa Ecuadoria. Poverty, which is one of the most important factors in the causation of tuberculosis, is being partially offset by the introduction in several cities of popular restaurants where good food is supplied at popular prices. Milk stations are also furnishing milk free to the infants of poor families. Several hundred dwellings have been destroyed and their place taken by many hygienic houses for workers

\section{Historical Medicine and Science}

Schumax's, of 30 East 70th Street, New York, have sent us their latest catalogue entitled "Medical Miscellany, List 'D'," containing an annotated list of rare books and first editions of works on historical medicine and science. In a special section on war medicine are listed the "Opera omnia medica et chirurgica" of Botallo (1660), James Handley's "Colloquia Chirurgica" (1705), Thomas Trotter's "Observations on the Scurvy" (1792), George Guthrie's treatise on "Gun-shot wounds" (1815), and William Braisted's "Report on the Japanese and Russian Medical Organization in the Russo-Japanese War" (1906) among many others. Mention may also be made of Pico della Mirandola's "Opera Omnia" (1506), the third Latin translation of Rhazes' works (1510), Thomas Willis's "De anima brutorum" (1672), Astruc's "De morbis venereis" (1740), David Brewster's "Treatise on the Kaleidoscope" (1819), Johannes Mueller's "Handbuch der Physiologie des Menschen" (1835-40), Cockayne's "Leechdoms, Wortconning and Starcraft of Early England" (1864-66), Allbutt's work on "The Use of the Ophthalmoscope" (1817), and Haeser's "Lehrbuch der Geschichte der Medicin", (1875-82).

\section{Admiral Dumont d'Urville (1790-1842)}

By a terrible railway accident at Versailles on May 8, 1842, France lost one of her most eminent scientific explorers, Admiral Jules-Sébastien-César Dumont d'Urville, whose voyages not only added much to geographical knowledge but also enriched immensely the natural history collections of the Paris museums. Born in Normandy on May 23, 1790, d'Urville entered the Navy at the age of eighteen, and two years later in the Chevrette visited the Black Sea. In the Isle of Milo his attention was turned to the famous statue of Venus, which was afterwards bought by the French Ambassador to Constantinople and now stands in the Louvre. In 1822 d'Urville was appointed to the Coquille, commanded by Duperrey, and in the course of a voyage in Oceania he made a collection of three thousand plants and another of twelve hundred insects. Returning home in 1825, he was appointed to the command of the ship, which was then renamed the Astrolabe. Leaving Toulon on April 25, 1826, the ship visited Australia, New Zealand, New Caledonia, New Guinea, the Carolines and other islands in the Pacific. The ship finally reached France again on March 25, 1829. D'Urville's last voyage, made during 1837-40 in the Astrolabe, accompanied this time by the Zélee, took him to the Antarctic. It was while he was engaged in writing the account of this voyage that he met his death. The train he was in caught fire, and the carriage doors being locked, some fifty-two persons, including d'Urville's wife and son, were burnt to death.

\section{Photography in Science, Medicine and Industry}

THस Association of Scientific Workers is organizing an exhibition which, it is hoped, will be held in November at the premises of the Royal Photographic Society. The exhibition is to illustrate the applications of photography to science, medicine and indus. try with the view of making such information more generally available and better known to the public. The Photographic Committee of the Association, anxious to obtain examples of such work from as wide a variety of sources as possible, appeals to those who may be able to provide exhibits to write to the Honorary Secretary, Photographic Exhibition Committee, Association of Scientific Workers, 73 High Holborn, London, W.C.1, for further details.

\section{Announcements}

Dr. Helen Bancroft (Mrs. Simmons), known for her work, especially at the Imperial Forestry Institute, on the anatomy of recent and fossil plants, floral anatomy and systematic botany, is interned, with her husband, at Vittel. She would be very glad to receive letters from her scientific friends during her isolation from scientific life. Her address is : Mrs. Helen Holme Simmons, Frontstalag 194, No. 111 Grand Hôtel, Vittel (Vosges), France.

THE Association of Scientific Workers has formed a committee to help in solving the special problems with which foreign men of science in Great Britain are confronted in assisting in the war effort. Foreign scientific workers interested in the work of this committee should write to the Secretary, Foreign Scientists Committee, Association of Scientific Workers, Hanover House, 73 High Holborn, W.C.1.

ERRATUM : In the communication from Dr. J. J. Monteverde which appeared in Nature of April 25, p. 472, the antigenic formula of Salmonella bonariensis, through an oversight, lacks the symbol for phase 1 of the flagellar antigen. The complete formula is $\mathrm{VI}_{1} . \mathrm{VIII} ; i \longleftrightarrow e, n$. .... (phase 2 is still under examination). 